\title{
DETERMINING THE FACTORS RELATED TO FIRST TIME POSTNATAL BREASTFEEDING
}

\author{
Armita Mayang Sari \\ Department of Biostatistics and Population, Faculty of Public Health, Universitas Airlangga, 60115 Surabaya, East Java, \\ Indonesia \\ Corresponding Author: Armita Mayang Sari \\ E-mail: f.armita.fa@gmail.com
}

\begin{abstract}
Infant Mortality Rate (IMR) is a problem in Indonesia that must be addressed in various aspects. New-borns need more attention in fulfilling their intake for growth and development. The best baby intake for early life after childbirth is exclusive breast milk. The importance of the time when breastfeeding is first given is closely related to the success of the Early Breastfeeding Initiation (EBI). Besides being able to handle the problem of infant intake, EBI is useful in strengthening the relationship between mother and child due to the interactions formed during breastfeeding. The goal to be achieved by researchers is to determine factors related to the time when breastfeeding was first given after birth. This type of research is analytic descriptive using the Spearman correlation test and chisquare statistical tests. The data used are secondary data from the Indonesian Demographic and Health Survey (IDHS) in 2017. The results of the descriptive analysis of the study are that the majority of mothers as respondents gave breastfeeding for the first time immediately at $62.8 \%$. The results of the bivariate analysis of the study are the relationship between maternal parity $(p=0.001$ and $r=-0.072)$, infant birth weight $(p=0.03$ and $r=0.049)$, area of residence $(\mathrm{p}=0.013)$ and type of delivery $(\mathrm{p}=0.013) \mathrm{p}=0.001)$ to the time of first breastfeeding.
\end{abstract}

Keywords: infant mortality rate, exclusive breast milk, early breastfeeding initiation

\begin{abstract}
ABSTRAK
Angka Kematian Bayi (AKB) merupakan permasalahan di Indonesia yang harus ditangani dari berbagai aspek. Bayi yang baru lahir membutuhkan perhatian yang lebih dalam pemenuhan asupan untuk pertumbuhan dan perkembangannya. Asupan bayi yang terbaik bagi awal kehidupan pasca persalinan adalah Air Susu Ibu (ASI) eksklusif. Pentingnya waktu saat ASI diberikan pertama kali erat kaitannya dengan keberhasilan Inisiasi Menyusu Dini (IMD). Selain dapat menangani permasalahan asupan bayi, IMD bermanfaat dalam mempererat hubungan ibu dan anak akibat interaksi yang terbentuk saat menyusui. Tujuan yang ingin dicapai peneliti yaitu menentukan faktor yang berhubungan dengan waktu saat ASI diberikan pertama kali pasca kelahiran. Jenis penelitian yang digunakan adalah deskriptif analitik menggunakan uji korelasi spearman dan uji statistik chi square. Data yang digunakan merupakan data sekunder hasil Survey Demografi dan Kesehatan Indonesia (SDKI) tahun 2017. Hasil analisis deskriptif dari penelitian yaitu mayoritas ibu sebagai responden telah memberikan ASI pertama kali secara segera sebesar $62,8 \%$. Hasil analisis bivariat dari penelitian yaitu adanya hubungan antara paritas ibu $(p$ $=0,001$ dan $r=-0,072)$, berat badan kelahiran bayi $(p=0,03$ dan $r=0,049)$, daerah tempat tinggal $(p=0,013)$ dan jenis persalinan $(p=0,001)$ terhadap waktu pemberian ASI pertama kali.
\end{abstract}

Kata kunci: angka kematian bayi, air susu ibu, inisiasi menyusu dini

Received: January 4, 2020

Accepted: February 20, 2020

\section{INTRODUCTION}

The child's golden period is the fastest growth and development period of the child throughout life. The golden period or commonly called the golden age takes place only once in a lifetime and is very determining about human qualities (Trenggonowati and Kulsum, 2018). The golden period generally lasts from the womb until the age of 6 months.
However, children will continue to develop rapidly until the age of 4 years.

A child growth is not only about increasing height or weight, but also the development of intelligence that is compulsory during his life. One of the most influential factors on a child's growth and development from prenatal to postnatal is the nutritional intake obtained by the child himself. The type of intake given 
concerning the fulfilment of a child's nutrition varies according to his age. Nutritional intake that can be given to new-borns is not arbitrary. In general, mothers only provide milk since babies cannot digest the food that is too dense in texture.

Furthermore, fulfilling the nutritional status of new-borns can contribute to the reduction in infant mortality or commonly known as IMR. IMR is the main indicator of public health quality in Indonesia, which is still a problem today (Lestari, 2018). The direct factors that cause high number of IMR in Indonesia can be categorized into medical factors and maternal factors. The medical factors mentioned can be in the form of Low Birth Weight (LBW), asphyxia, infection, and hypothermia. Additionally, maternal factors that cause IMR including maternal age that exceeds or is less than the limit of the low risk of pregnancy, the large number of children who have been born, the age gap between children that is too close, the view about colostrum that is not right, and breastfeeding is not based on the recommendations.

In contrast to the direct factors of infant mortality that have been described, the more indirect causes come from the lack of socialenvironmental support, lack of awareness and knowledge about the importance of examinations during pregnancy, and low access to health care facilities (Fauziah, 2009).

Theoretically, the fulfilment of nutritional status in infants plays a role in handling health problems such as stunting and wasting. According to the previous studies, breastfeeding tends to affect the nutritional status of toddlers aged 6 to 24 months (Dewi, 2010).

Breast milk is the intake of new-borns that originate only from a woman. Biologically, breast milk can also be interpreted as a fat emulsion resulting from the excretion of the mother's breast glands (Agustia, 2013). Breast milk contains enough nutrients in fulfilling the nutritional status of infants and a protective factor from several health problems. Proper breastfeeding can be a protection for infants against exposure to infectious and allergic diseases.

Exclusive breastfeeding within the first hour after birth or commonly called Early Breastfeeding Initiation (EBI) is highly recommended by the government. In addition to its role in fulfilling the nutritional status of new- borns, EBI aims for the baby to be in direct contact with the mother's skin and swallow good bacteria that will form immune system for the baby, increase the quality of motherchildren relationship, reduce bleeding, and reduce the occurrence of anaemia (Indonesian Ministry of Health, 2014).

The interaction formed through EBI has a greater influence concerning the smoothness of breast milk for up to 4 months (Rahardjo, 2003). But, unfortunately, there are still many mothers who do not breastfeed their children directly up to two days or do not breastfeed at all. EBI coverage according to Basic Health Research data states that number of breastfeeding activities for the first time in less than 1 hour postnatal is $34.5 \%, 1$ to 6 hours postnatal is $35.2 \%, 7$ to 23 hours postnatal is $3.7 \%, 24$ to 47 $13 \%$ postnatal hours, and more than 48 postnatal hours $13.7 \%$ (Indonesian Ministry of Health, 2013).

Many factors affect the time of first breastfeeding after the birth of a baby, one of which is closely related to the theory of behavioural determinants raised by Lawrence Green. According to Green in Notoatmodjo, there are two determinants of human behavior, namely behavioral and non-behavioral factors (Notoatmodjo, 2005). Based on these determinants, Green adds three main factors that influence health behaviour. The three factors in question are predisposing factors, enabling factors, and driving factors.

Related research showed that there are several significant factors related to the time of exclusive breastfeeding for the first time to the baby. These factors including the level of maternal education, the type of childbirth taken, counseling undertaken during pregnancy, and the support of health workers (Fauziah, 2009). However, the study was only limited to patients in hospitals in Jakarta in 2009.

Based on the background description stated, this study was conduucted to find out more deeply about the factors that influence the time when breastfeeding was first given after birth extensively in Indonesia using the IDHS 2017 data. Factors that will be examined for the effects on the time of first breastfeeding including maternal age, mother's level of education, maternal parity area of residence, type of last childbirth, birthweight, and health facilities chosen at delivery. The research is also expected to help stakeholders, especially the government, concerning fulfilling the target of 
EBI coverage to deal with several infant health problems.

\section{METHODS}

Research on determining factors that influence the time when breastfeeding is first given after birth is analytical descriptive with a cross-sectional design. The population in this study is all women of childbearing age in Indonesia according to the population of the Indonesian Health Demographic Survey (IDHS) in 2017. The samples taken are part of the population with criteria that fit the research objectives and meet the required variables. The criteria in this study consisted of female respondents in Indonesia who had given birth to a baby a year before the data collection and had complete data in the form of the time of first breastfeeding.

The research technique in collecting secondary data for the 2017 IDHS used a documentation approach. The 2017 IDHS data was obtained from the web site Demography and Health Survey (DHS) (2017).

Data analysis is a relationship test between the independent variable and the dependent variable, namely the time of first breastfeeding after birth using the Spearman and chi-square correlation test. Spearman correlation testing is performed on independent variables that have ordinal data scales, while chi-square testing is done on independent variables that have nominal data scales. Testing is done to find the relationship between the variables studied with a confidence level of 95\% through the help of SPSS and Microsoft Excel 2010 applications. Data analysis will be displayed in tabular form followed by narration.

\section{RESULT}

\section{General Characteristics of Mother}

Table 1. illustrates the general characteristics of mothers as respondents in the form of age, education is taken, area of residence, type of delivery at the time of giving birth to the last child, health facilities to be addressed at the birth of the last child, and parity of mothers with a total of 1953 respondents.

The results of the study in table 1 showed that the most respondents were in the age distribution interval of 26-30 years with the number $532(27.2 \%)$, while the frequency of
Table 1. General Characteristics of Mother

\begin{tabular}{lrr}
\hline & $\begin{array}{c}\text { Amount } \\
(\mathbf{n = 1 9 5 3 )}\end{array}$ & $(\boldsymbol{\%})$ \\
\hline Age & & \\
\hline$<15$ & 161 & 8.2 \\
$21-25$ & 447 & 22.9 \\
$26-30$ & 532 & 27.2 \\
$31-35$ & 513 & 26.3 \\
$36-40$ & 232 & 11.9 \\
$41-45$ & 62 & 3.2 \\
$>45$ & 6 & 0.3 \\
\hline Area of Residence & & \\
\hline Urban & 990 & 50.7 \\
Rural & 963 & 49.3 \\
\hline Level of education & & \\
\hline No school & 7 & 0.4 \\
Basic education & 391 & 20.0 \\
Middle education & 1,134 & 58.1 \\
Higher education & 421 & 21.6 \\
\hline
\end{tabular}

Table 2. Characteristics of Mothers Relation to the Childbirth of the Last Child

\begin{tabular}{lrr}
\hline & $\begin{array}{c}\text { Amount } \\
(\mathbf{n = 1 9 5 3 )}\end{array}$ & $\mathbf{( \% )}$ \\
\hline Type of & & \\
Childbirth & & \\
\hline Spontaneous & 1,571 & 80.4 \\
Cesarean section & 382 & 19.6 \\
\hline Childbirth & & \\
\hline House & 296 & 15.2 \\
Government & 743 & 38.0 \\
PHC/Hospital & & \\
Private midwife & 53 & 2.7 \\
Private & 858 & 43.9 \\
PHC/Hospital & & \\
Others & 3 & 0.2 \\
\hline Parity & & \\
\hline Primipara & 641 & 32.8 \\
Multipara & 1,206 & 61.8 \\
Grande multipara & 106 & 5.4 \\
\hline
\end{tabular}

respondents with the smallest number was at the age interval of 46-50 years with the number of 6 respondents $(0.3 \%)$. Respondent's residential area represents 990 respondents $(50.7 \%)$ residing in urban areas and 963 respondents $(49.3 \%)$ residing in rural areas. In the education category, the majority of mothers had completed secondary education with a figure of $1134(58.1 \%)$ and only as many as 7 respondents who had not attended any education $(0.4 \%)$. 
Table 2. shows the general description of the respondent as a mother about the last childbirth including the majority of respondents gave birth spontaneously with a figure of 1571 or $80.4 \%$ with private-owned health facilities were chosen for delivery with a figure of 858 or equal to $43.9 \%$. Moreover, mothers with multipara parity classification were more numerous than primipara and grandemultipara with 1206 respondents $(61.8 \%)$.

\section{Characteristics of Respondent Infants}

Table 3. shows a description of the frequency distribution of the birth weight of respondents. The majority of infants are included in the normal category about bodyweight with 1835 (94\%), but there are still many infants born with Low Birth Weight (LBW) of 112 infants $(5.7 \%)$ and Very Low Birth Weight (VBWR) with a total of 6 infants $(0.3 \%)$.

Table 3. Infant Birth Weight

\begin{tabular}{lcc}
\hline $\begin{array}{c}\text { Infant Birth } \\
\text { Weight }\end{array}$ & Frequency & $\mathbf{( \% )}$ \\
\hline Normal & 1,835 & 94.0 \\
LBW & 112 & 5.7 \\
VLBW & 6 & 0.3 \\
\hline amount & 1.953 & 100.0 \\
\hline
\end{tabular}

\section{First Time Breastfeeding}

Table 4. illustrates the number of mothers categorized according to the time of first breastfeeding after birth. The categories of time for breastfeeding are first divided into 4: immediately within 1 hour after giving birth, 1 to 23 hours after giving birth, 24 to 48 hours after giving birth, and more than 48 hours.

Table 4. The time when breastfeeding was first given to infants

\begin{tabular}{lrr}
\hline $\begin{array}{c}\text { The time when the } \\
\text { breastfeed was first } \\
\text { given }\end{array}$ & frequency & $\mathbf{( \% )}$ \\
\hline Immediately & 1,227 & 62.8 \\
1 hour - 23 hours & 269 & 13.8 \\
24 hours - 48 hours & 133 & 6.8 \\
$>$ 48 hours & 324 & 16.6 \\
\hline amount & 1,953 & 100,0 \\
\hline
\end{tabular}

The number of respondents who gave breastfeed immediately to their infants was much more compared to the other categories with a total of 1,227 (62.8\%). Meanwhile, many infants are given breast milk more than 48 hours or more than 2 days after birth with a rate of 324 or equivalent to $16.6 \%$ of the total distribution of respondents.

The Relationship between Maternal Age, Education Level, Maternal Parity, and Infant's Birth Weight with the Time When First Breastfeeding was Given

Table 5. shows the results of the Spearman correlation test. The relationships studied were maternal age in years, education was taken by the mother, maternal parity, and infants' birth weight with ordinal data on the dependent variable i.e. when breastfeeding was first given after birth. Related factors will show the value of $p<0.05$ and vice versa.

Table 5. Relationship of Mother's Age, Education Level, Parity, and Infant's Birth Weight with the First Time Breastfeeding

\begin{tabular}{lrr}
\hline & r & $\boldsymbol{p}$ \\
\hline Mother's age & 0.008 & 0.737 \\
Level of education & 0.035 & 0.124 \\
Parity & -0.072 & 0.001 \\
Infant's Birth Weight & 0.049 & 0.03 \\
\hline
\end{tabular}

Spearman correlation test results between independent variables that scale ordinal data to the time of first breastfeeding showed the pvalue on the maternal parity variable was 0.001 and the p-value on the baby's birth weight was 0.03 . Both showed the p-value did not pass the confidence interval $(95 \%)$ which meant that there is a relationship between maternal parity and infant's birth weight with the first-time breastfeeding. Whereas the variables of maternal age and level of education indicate the value of $\mathrm{p}$ past the confidence interval (95\%), which means there is no relationship between the two of them at the first-time breastfeeding after birth.

Spearman correlation coefficient $(r)$ in maternal parity of -0.072 , which indicates a low and opposite direction relationship. Contrary to the intended direction, namely when more parity occurs, the time of first breastfeeding gets smaller (faster) and vice versa. In the baby birth weight variable, the Spearman correlation coefficient shows the number 0.049 which means that the relationship is low and direct. 
Table 6. Chi-Square Test Results between Area of Residence, Type of Childbirth, and Place of Childbirth with the Time of First Breastfeeding

\begin{tabular}{lrrc}
\hline \multicolumn{1}{c}{ Variable } & F & \% & $\boldsymbol{p}$ \\
\hline Area of Residence & & & 0.013 \\
Urban & 990 & 50.7 & \\
Rural & 963 & 49.3 & 0.001 \\
\hline Type of delivery & & & \\
Spontaneous & 1571 & 80.4 & 0.1 \\
Caesarean section & 382 & 19.6 & \\
\hline Place of delivery & & & \\
House & 296 & 15.2 & \\
Government PHC/Hospital & 743 & 38.0 & \\
Private midwife & 53 & 2.7 & \\
Private PHC/Hospital & 858 & 43.9 & \\
Others & 3 & 0.2 & \\
\hline
\end{tabular}

Unidirectionally meant is the increase in birth weight of the baby will result in a faster time of breastfeeding the first time after birth and vice versa.

The Relationship between Area of Residence, Type of Childbirth, and Place of Childbirth with the Time when First Breastfeeding was Given

The second bivariate analysis was performed using a chi-square test on all variables on a categorical data scale to see the relationship to the dependent variable, which is the time when first breastfeeding was given after delivery. Table 5 illustrates the relationship between the area of residence of the respondent, the type of the last delivery performed, and the place of delivery chosen.

In the area of residence, the variable shows that the number of respondents who gave breastfeeding for the first time immediately was the majority of respondents who came from rural areas as many as 629 (32.2\%). Respondents who live in urban areas have a distribution that is not much different which is equal to 598 respondents $(30.6 \%)$. While in the variable type of delivery, the majority of respondents who did spontaneous delivery, breastfeed immediately with a total of 1091 respondents $(55.9 \%)$.

In the variable place of delivery, the number shown between categories does not indicate a significant difference. Respondents who breastfed immediately after giving birth are majority did the delivery in private-owned health facilities at $522(26.7 \%)$.
Table 6 shows that the variables related to the time of first breastfeeding after delivery were the area of residence with a $p$ of 0.013 and the type of delivery with a $\mathrm{p}$ of 0.001 . The relationship between the two is known from the $\mathrm{p}$ value that does not pass the confidence interval $(95 \%)$ through the test results. The place of delivery variable is not significantly related because the $p$ value that passes through the confidence interval is equal to 0.100 .

\section{DISCUSSION}

The speed of breastfeeding for the first time after birth is closely related to the success of the Early Breastfeeding Initiation (EBI). The first breast milk given in the first hour is very important for new-borns. One of the benefits obtained when the baby drinks breast milk in the first hour after birth is to provide the protective effect of infants from various infectious diseases (Kaban, 2017).

\section{Relationship between Mother's Age and Time when First Breastfeeding was Given}

One factor in the speed of breastfeeding for the first time after delivery is knowledge (Kaban, 2017). The level of knowledge influences the attitude of the mother who will give breast milk immediately to her infant within 30 minutes to the first hour of birth. Several studies have shown that knowledge is significantly related to the success of Early Breastfeeding Initiation or breastfeeding for the first time in the first hour.

This was proven in Heryanto's research which produced a p-value of 0.005 to test the 
relationship between knowledge and Early Breastfeeding Initiation. (Heryanto, 2015). Chisquare test conducted by Heryanto shows the relationship between knowledge and EBI because $\mathrm{p}$ does not pass through the confidence interval. A similar study was conducted by Ulandari and showed the same results, where the p-value was 0.007 , which means there is a relationship between maternal knowledge and Early Breastfeeding Initiation (Ulandari, 2018).

Knowledge about the time of first breastfeeding can be influenced by maternal age (Kaban, 2017). Increasing maternal age will influence the development of physical and psychological aspects regarding exclusive breastfeeding and Early Breastfeeding Initiation activities. Related research resulted in a p-value of 0.021 using the chi-square test (Mohamad, Rattu, and Umboh, 2015). Categories in the age of respondents are divided into adult age is $>25$ years and the teenage age is $\leq 25$ years. A pvalue of fewer than 0.05 means that there is a relationship between the age of the mother as a respondent to the Early Breastfeeding Initiation. Research conducted by Adam, Alim, and Sari (2016) which states the relationship between mother's knowledge and Early Breastfeeding Initiation variables at Makassar Regional Hospital.

This study shows the results of the analysis that is different from the theories as well as previous studies available. The age of the majority of mothers is the ideal age at birth, which is 26 to 35 years, does not make it quite related to the time of breastfeeding for the first time after the infant was born. Spearman correlation test shows the $\mathrm{p}$ value of 0.737 , which means there is no relationship between the age of the mother as a respondent to the time of first breastfeeding after delivery.

\section{Relationship Education Level and The Time when First Breastfeeding was Given}

Education can make a person knowledgeable and ultimately will increase the information obtained (Kaban, 2017). When a person attends enough education, more information is obtained. The information in question is very diverse, one of which the knowledge of the right time for breastfeeding for the first time is to succeed in Early Breastfeeding Initiation.

A previous study conducted by Ulandari showed a relationship between the last education that was undertaken by respondents with the Early Breastfeeding Initiation. The pvalue based on testing shows the number 0.023 which means that $p$ does not pass the confidence interval or there is an educational relationship that is taken with the Early Breastfeeding Initiation. This variable is in line with the knowledge variable which shows a significant relationship to Early Breastfeeding Initiation. Ulandari assumes that the high level of education a mother goes through will increase awareness in Early Breastfeeding Initiation activities (Ulandari, 2018).

Ulandari's research shows differences in results with research that states the results are not significant on education level variables with the time of first breastfeeding given after birth. The majority of mothers' education only reached the middle level does not provide a significant relationship to the time of first breastfeeding given after birth. The cause of testing the insignificant relationship between the level of education with the time of first breastfeeding after birth is the fairly even distribution of time the mother gave breastfeeding for the first time in each group of educational level history. The p-value passed through the confidence interval using the Spearman correlation test, which means that there was no educational relationship that the mother had taken and when breastfeeding was first given after birth (Ulandari, 2018).

\section{Relationship between Mother Parity and Time when First Breastfeeding was Given}

Parity is a factor that can influence maternal attitudes in the speed of breastfeeding for the first time after giving birth. The definition of parity itself is a woman who can give birth to children (dead or alive) (Ekasari, 2015). Types of parity can be divided into 4 : nullipara, primipara, multipara, and grande multipara. The type of parity is based on the number of infants born and are able to live. The number of babies ever born in the primipara category is 1 , multipara 2 to 4 babies, grande multipara is 5 or more babies, and in the nullipara category, it means that the woman has never given birth to an alive infant.

Mothers who gave birth $\geq 2$ had a better experience in giving birth and breastfeeding compared to nullipara and primipara mothers (Issyaputri, Ansar and Arsyad, 2012). This statement is in line with this study which states that there is a relationship between parity and time of first breastfeeding in infants. Spearman 
correlation test analysis results showed a pvalue of 0.001 with a correlation coefficient of -0.072 . The $p$-value does not exceed the confidence interval indicating there is a relationship between maternal parity and the time when breastfeeding was first given, while the Spearman correlation coefficient values describe the direction and magnitude of the relationship between testing between maternal parity and the time of first breastfeeding.

The relationship formed is quite low because of the large difference between maternal parity with the speed of the mother in breastfeeding for the first time after delivery. The majority of mothers with multipara status as many as 1206 people will be faster in breastfeeding for the first time compared to primiparous mothers, amounting to 641 people. This is because mothers who have given birth before have more experience in breastfeeding immediately after giving birth. This is also evidenced by the Spearman correlation coefficient which shows the direction of the negative relationship.

\section{Relationship between Birth Weight of Babies and the Time when First Breastfeeding was Given}

Infant's weight can be classified into 4 , which are normal with a weight exceeding 2500 grams, Low Birth Weight (LBW) with a weight between 1500 - 2500 grams, Very Low Birth Weight (VLBW) with a weight between 1000 1500 grams, and Extreme Low Birth Weight (ELBW) weighing less than 1000 grams (Ekasari, 2015). Infants need to get exclusive breast milk, especially infants who are in LBW, BBLSR, and BBLER categories. Research on the relationship between birth weight and exclusive breastfeeding during the first hour after birth was stated by Rahardjo. The study states that there is a relationship between the two and is driven by labor aids (Rahardjo, 2003).

In line with Rahardjo's research, this study produced a p-value of 0.03 and a Spearman correlation coefficient of 0.049 . The resulting $p$ number does not exceed the confidence interval or there is a significant relationship between the birth weight of the baby with the time of first breastfeeding after giving birth.

Furthermore, the correlation coefficient can explain that the magnitude of the relationship formed is low. This is caused by differences in the proportions of infants' birth weight that are quite far between normal, low, and very low. The majority of infants born with normal birth weight according to the data are 1,835 infants. Infants with normal birth weight have more stable body conditions compared to infants with LBW and LBWR status that must be given treatment by health workers first. This can be one of the factors that causes significant test results. The direction of the relationship that is formed is the same direction in which the increase in infant's birth weight status results in more rapid giving of breast milk for the first time after delivery.

\section{Relationship between Regional Residence and Time when First Breastfeeding was Given}

The area of residence can be divided into 2 : urban and rural areas. A regional factor of residence is closely related to adequate health facilities in childbirth. According to Irawati (2010), urban health facilities have further hampered the success of Early Breastfeeding Initiation due to the large amount of formula milk that has been provided after the birth of a baby.

This study examines the relationship between respondents' residential areas and the time of first breastfeeding with the selected bivariate test. The majority of respondents included in the test residing in urban areas by $50.7 \%$ which means that more respondents had adequate access and information that was quickly conveyed with the best time for firsttime breastfeeding after delivery. The resulting p-value is 0.013, which means there is a relationship between the mothers' residential areas with the time of first breastfeeding was given to the baby.

\section{The Relationship between Type of Delivery and Time when First Breastfeeding was Given}

Type of delivery can be divided into 2 : normal and abnormal delivery (Bernita, 2017). Normal delivery is a process undertaken by pregnant women without any artificial action or help or complications, while an abnormal one is better known as caesarean section (C-Section).

In a previous study by Putri, Hasanah and Ahsan (2017) regarding the relationship between the types of delivery and the success of Early Breastfeeding Initiation states, there is a relationship between the two. This study shows 
the compatibility with previous studies, namely the relationship between the type of delivery and time when breastfeeding was first given after giving birth. Bivariate testing showed a pvalue of 0.001 .

This can be resulted from a mother with a type of delivery surgery who must receive medical treatment and rest first compared to women with the type of spontaneous delivery that can immediately recover. The proportion of spontaneous or normal delivery was higher in the proportion with 1571 mothers who made it possible to give breastfeeding for the first time immediately after delivery.

\section{Relationship Between Delivery and Time when First Breastfeeding was Given}

Health workers and health facilities have a significant role in the implementation of Early Breastfeeding Initiation (Kaban, 2017). Both have different characteristics according to the policies and organization of a health facility. Health facilities that can be chosen as a place of delivery are UKBM, health facilities with government ownership, health facilities with private ownership, and other health facilities. Besides, the house can also be used as an option for delivery as long as there are competent health workers.

One of the variables studied about the time of first breastfeeding is the place of delivery. The most preferred delivery places chosen by respondents are the delivery places owned by the government and the private sector with figures reaching 700 to 850 respondents. The place of delivery chosen is a health facility with adequate medical devices and competent health workers in the effort to give breastfeeding for the first time immediately after delivery. However, some respondents chose to give birth at home as many as 296 people. This can be a serious problem if treatment is not carried out by competent health workers.

Testing the bivariate relationship states there is no relationship between the place of delivery and the time of first-time breastfeeding with a p-value of 0.100 . This is contrary to the results of previous studies regarding the factors associated with Early Breastfeeding Initiation. Using the same test, the resulting p-value is 0.002 , which means there is a relationship between the place of delivery and Early Breastfeeding Initiation (Norhana, Arifin, and Yulidasari, 2016).

\section{CONCLUSIONS AND SUGGESTIONS}

\section{Conclusion}

The results showed that thes majority of mothers in Indonesia according to the 2017 IDHS data give first breastfeeding immediately after giving birth or within the first hour. Influence factors that cause differences in the time when first breastfeeding was given include maternal parity, infant's birth weight, residential area, and type of delivery.

\section{Suggestion}

The government and health workers work together to increase the success of the Early Breastfeeding Initiation by promoting the best possible time for breastfeeding as soon as possible or the first hour after birth. Giving counselling about the best time for breastfeeding for the first time should be focused on mothers who are giving birth for the first time. This socialization expects that mothers who lack information about Early Breastfeeding Initiation understand and apply it.

\section{REFERENCES}

Adam, A., Alim, A., and Sari, N.P., 2016. Pemberian Inisiasi Menyusu Dini pada Bayi Baru Lahir. Jurnal Kesehatan MANARANG, 2 (2), pp.76-82.

Agustia, E., 2013. Faktor-Faktor yang Mempengaruhi Pemberian ASI Eksklusif pada Bayi Usia 0-6 Bulan. Thesis. Universitas Muhammadiyah Ponorogo.

Bernita, L. M. N., 2017. Klasifikasi Persalinan Normal atau Caesar Menggunakan Algoritma C4.5. Thesis. Universitas Sanata Dharma.

Dewi, N. R., 2010. Hubungan Pola Asuhan Gizi dengan Status Gizi Balita Usia 6-14 Bulan di Wilayah Kerja Puskesmas Tinggimoncong Kab. Gowa. Thesis. Universitas Islam Negeri Alauddin Makassar.

Ekasari, W.U., 2015. Pengaruh Umur Ibu, Paritas, Usia Kehamilan, dan Berat Lahir Bayi terhadap Asfiksia Bayi pada Ibu Pre Eklamsia Berat. Thesis. Universitas Sebelas Maret.

Fauziah, 2009. Faktor-Faktor yang Berhubungan dengan Waktu Menyusui Pertama Kali pada Bayi Baru Lahir di Rumah Sakit Umum Daerah Koja Jakarta. 
Thesis. Universitas Negeri Syarif Hidayatullah.

Heryanto, E., 2015. Faktor-Faktor yang Berhubungan dengan Pelaksanaan Inisiasi Menyusu Dini. Jurnal Ilmu Kesehatan Aisyah, 1 (2), pp.17-23.

Indonesian Ministry of Health, 2013. Riset Kesehatan Dasar: RISKESDAS. Jakarta.

Indonesian Ministry of Health, 2014. Infodatin: Situasi dan Analisis ASI Eksklusif. Jakarta.

Intermediate Care Facility, 2017. The Demographic and Health Survey (DHS) Program (DHS-7). United Stated: USAID.

Irawati, A., 2010. Inisiasi Menyusu Dini dan Faktor Determinannya pada Anak Balita di Indonesia. Puslitbang Gizi dan Makanan, 33 (1), pp. 1-13.

Issyaputri, A.F., Ansar, J. and Arsyad, D.S., 2012. Faktor yang Berhubungan dengan Ibu Melakukan Inisiasi Menyusu Dini (IMD) di RSIA Siti Fatimah Makassar Tahun 2011. Jurnal MKMI, 6 (2), pp.1724.

Kaban, N.B., 2017. Inisiasi Menyusu Dini. Jurnal Keluarga Sehat Sejahtera, 15 (2), pp.35-46.

Lestari, R.R., 2018. Faktor-Faktor yang Berhubungan dengan Pemberian ASI Ekslusif pada Ibu. Jurnal Obsesi: Jurnal Pendidikan Anak Usia Dini, 2 (1), pp.131136.

Mohamad, S., Rattu, A.J.M., and Umboh,
J.M.L., 2015. Faktor-faktor yang Berhubungan dengan Pelaksanaan Inisiasi Menyusu Dini oleh Bidan di Rumah Sakit Prof. Dr. Aloei Saboe Kota Gorontalo. Jikmu, 5 (2a), pp.390-396.

Norhana, A., Arifin, S. and Yulidasari, F., 2016. Hubungan Tempat Persalinan dan Jenis Penolong Persalinan dengan Pelaksanaan Inisiasi Menyusu Dini di Puskesmas Martapura. Jurnal Publikasi Kesehatan Masyarakat Indonesia, 3 (2), pp.51-58.

Notoatmodjo, S., 2005. Promosi Kesehatan Teori dan Aplikasi. Jakarta: Rineka Cipta.

Putri, R., Hasanah, N., and Ahsan, 2017. Hubungan Jenis Persalinan terhadap Keberhasilan Inisiasi Menyusu Dini (IMD) di RSUD Bangil Kabupaten Pasuruan. Majalah Kesehatan. 4 (4), pp. 183-192.

Rahardjo, S., 2003. Faktor-Faktor yang Berhubungan dengan Pemberian ASI Satu Jam Pertama. Jurnal Kesehatan Masyarakat Nasional, 1 (1), pp. 11-17.

Trenggonowati, D.L., and Kulsum, 2018. Analisis Faktor Optimalisasi Golden Age Anak Usia Dini. Journal of Industrial Services, 4 (1), pp.48-56.

Ulandari, D., 2018. Faktor-Faktor yang Mempengaruhi Pelaksanaan IMD pada Pasien Pasca Persalinan di BPM Ratna Wilis Palembang. Gaster, 16 (1), pp.6472. 